\title{
Analisis Kandungan Senyawa Kimia dan Uji Sifat Magnetik Pasir Besi Pantai Ambal
}

\author{
Bilalodin $^{(1)}$, Sunardi ${ }^{(2)}$ dan Muhtar Effendy ${ }^{(3)}$ \\ $(1,2,3)$ Program Studi Fisika, Jurusan MIPA Fakultas Sains dan Teknik Universitas Jenderal Soedirman \\ Jl. Dr. Soeparno No.61 Kampus Unsoed Karangwangkal 53123 \\ email: bilalodin.unsoed@gmail.com
}

\begin{abstract}
Abstrak - Analisis senyawa kimia dan uji sifat magnetic pasir besi telah dilakukan. Tujuan penelitian adalah mengetahui kandungan mineral magnetik dan sifat magnetik yang terdapat pada pasir besi pantai Ambal. Sampel pasir besi diambil dari pantai Ambal. Pasir diekstraksi dengan menggunakan magnet permanen untuk memisahkan pasir magnetik dan non magnetik. Pasir magnetik yang telah dipisahkan dilakukan pengujian jenis kandungan mineral dengan XRD (X-Ray Diffraction) dan uji sifat magnetiknya dilakukan menggunakan VSM (Vibrating Sample Magnetometer). Hasil penelitian menunjukkan jenis mineral magnetik pasir pantai Ambal Kecamatan Mirit Kabupaten Kebumen berbentuk senyawa Magnetite $\left(\mathrm{Fe}_{3} \mathrm{O}_{4}\right)$ dan Hematite $\left(\mathrm{Fe}_{2} \mathrm{O}_{3}\right)$. Perhitungan nilai suseptibilitas magnetik sebesar $31,88 \times 10^{-6} \mathrm{~m}^{3} / \mathrm{kg}$ Berdasarkan nilai permeabilitas relatif yang terhitung, mineral magnetik pasir pantai Ambal kecamatan Mirit Kabupaten Kebumen termasuk kategori feromagnetik.
\end{abstract}

Kata kunci: pasir besi, XRD (X-Ray Diffraction), VSM (Vibrating Sample Magnetometer

Abstract - Analysis of chemical compounds and test the magnetic properties of iron sand has been done. The research objective was to determine the content of magnetic minerals and magnetic properties of iron sand found on beaches Ambal. Iron sand samples taken from the beach Ambal. Sand extracted by using a permanent magnet to saparate magnetic and non magnetic sand. Magnetic sand that has been separated mineral content of the type of testing performed by XRD (X-Ray Diffraction) and magnetic properties of the test performed using a VSM (Vibrating Sample Magnetometer). Base on the results of study that magnetic mineral sands of Ambal District Mirit Kebumen contain Magnetite $\left(\mathrm{Fe}_{3} \mathrm{O}_{4}\right)$ and Hematite $\left(\mathrm{Fe}_{2} \mathrm{O}_{3}\right)$. The calculation of magnetic susceptibility values is $31.88 \times 10^{-6} \mathrm{~m} 3 / \mathrm{kg}$. Based on the calculated value of the relative permeability, magnetic mineral sands Ambal Mirit Kebumen district ferromagnetic category.

Key words: Iron Sand, XRD (X-Ray Diffraction), VSM (Vibrating Sample Magnetometer)

\section{PENDAHULUAN \\ Indonesia memiliki bahan magnetik alam yang} melimpah. Bahan magnetik alam tersebut diantaranya terdapat di dalam pasir besi. Pasir besi di Indonesia melimpah dan banyak terdapat di pulau Jawa khususnya di pantai utara dan selatan. Selama ini pasir besi pada umumnya dijadikan sebagai bahan bangunan padahal pasir besi mengandung bahan mineral magnetik yang merupakan basis untuk pengembangan divais dalam kehidupan modern. Pasir besi yang telah dipisahkan dari material non magnetik banyak digunakan sebagai bahan dalam pabrik baja, bahan peleburan besi dan juga campuran semen. Di pihak lain mineral magnetik yang mengandung magnetit, hematit, dan maghemit mempunyai potensi besar dalam pengembangan industri[1].

Pantai selatan yang banyak mengandung pasir besi diantaranya Cilacap dan Kebumen. Hasil penelitian Bilalodin (2010) di daerah Cilacap menunjukkan adanya kandungan mineral magnetit pada pasir besi daerah tersebut yang bersifat feromagnetik. Hal sama juga ditemukan pada pantai Logending. Pada pantai Logending ditemukan bahwa pasir besi mengandung $\mathrm{Fe}_{3} \mathrm{O}_{4}$ [2].
Berdampingan dengan pantai Logending adalah pantai Ambal yang terdapat di kecamatan Mirit kabupaten Kebumen. Guna menggali potensi pada pasir besi pantai Ambal perlu dilakukanan analisis kandungan senyawa kimia dan karakterisasi sifat magnetiknya. Pengungkapan kandungan mineral dan sifat magnetik pair besi pantai Ambal diharapkan dapat ditemukan senyawa yang unik dan bermanfaat bagi pengembangan industri sehingga akan dapat meningkatkan pendapatan daerah.

\section{METODE PENELITIAN \\ Bahan dan Peralatan}

Bahan yang digunakan dalam penelitian ini adalah pasir yang diambil dari wilayah pantai Ambal. Peralatan yang digunakan antara lain: sekop, botol kaca, gelas ukur, penumbuk pasir, penyaring, neraca digital (O-haus), Seperangkat alat $X$-Ray Diffraction, Phillips dan VSM (Vibrating Sample Magnetometer) tipe Oxford $1.2 \mathrm{H}$

\section{Eksperimental dan Analisis}

Preparasi sampel diawali dengan mengeringkan pasir besi pada suhu $100{ }^{0} \mathrm{C}$ untuk menghilangkan kandungan air. Selanjutnya dilakukan proses pemisahan 
(ekstraksi) kandungan bahan-bahan magnetik dari pasirnya menggunakan magnet permanen. Pasir yang bersifat magnetik dikarakterisasi menggunakan peralatan XRD. Kemudian dianalisa kandungan mineralnya berdasarkan data jarak bidang (d), sudut dua theta $(2 \theta)$ yang dibandingkan atau pencocokan dengan referensi (Handbook of Mineral arranged by $X$-ray Powder Diffraction). Sedangkan karakterisasi magnetik menggunakan metode VSM. Hasil karakterisasi VSM diperoleh kurva histerisis. Berdasarkan kurva tersebut dapat diketahui besaran-besaran kemagnetan yaitu magnetisasi saturasi $\left(M_{s}\right)$, magnetisasi remanen $\left(M_{r}\right)$ dan medan koersivitas $\left(\mathrm{H}_{\mathrm{c}}\right)$. Kemudian besaran-besaran tersebut dianalisis lebih lanjut untuk mendapatkan nilai suseptibilatas magnetik $\left(\mathrm{X}_{\mathrm{m}}\right)$ dan permeabilitas magnetik $\left(\mu_{\mathrm{m}}\right)$ melalui persamaan (1) dan (2) [3]

$$
\bar{M}=X_{m} \bar{H}
$$

dan

$X_{m}=\mu_{r}-1$

$$
\text { dengan } \quad \mu_{r}=\frac{\mu}{\mu_{0}}
$$

\section{HASIL DAN PEMBAHASAN}

Pasir besi di wilayah Pantai Ambal mempunyai karakteristik antara lain berwarna hitam, mengandung mineral magnetik $21 \%$ pasir dan non magnetik $79 \%$. Nilai massa jenis pasir rata-rata $1,6 \mathrm{~g} / \mathrm{cm}^{3}$. Nilai tersebut mendekati massa jenis pasir yaitu berkisar antara 1,20-1,80 $\mathrm{g} / \mathrm{cm}^{3}[4]$.

Hasil indentifikasi senyawa kimia sampel pasir besi menggunakan difraksi sinar $\mathrm{X}$ diperoleh 3 buah puncak dominan yaitu pada sudut $2 \theta$ yaitu $35,6634^{\circ}, 30,3918^{0}$, dan $27,8000^{\circ}$. Puncak-puncak yang dominan tersebut dilakukan searchmach dengan Handbook of Mineral arranged by X-ray Powder Diffraction, diperoleh jenis senyawanya yang terkandung adalah Magnetite $\left(\mathrm{Fe}_{3} \mathrm{O}_{4}\right)$, Hematite $\left(\mathrm{Fe}_{2} \mathrm{O}_{3}\right)$, Magnetite Iron Magnesium Chromium Oxide $(\mathrm{Fe}, \mathrm{Mg})(\mathrm{Cr}, \mathrm{Fe})_{2} \mathrm{O}_{4}$. Gambar hasil XRD pasir besi diambil di tempat di wilayah pesisir Pantai Ambal diperlihatkan pada Gambar 1

Hasil karakterisasi sampel pasir magnetik menggunakan VSM diperoleh kurva histerisis seperti diperlihatkan pada Gambar 2. Berdasarkan analisis kurva histerisis diperoleh besarnya medan remanen tanpa adanya medan magnet luar ( $\bar{H}$ luar $=0$ Tesla menghasilkan magnetisasi remanen $(\bar{M})$ sebesar 5,550926 $\mathrm{emu} / \mathrm{gr}$ dan medan luar $\mathrm{H}_{\text {maks }}$ sebesar 0,999 $\mathrm{T}$ diperoleh magnetisasi remanen $\mathrm{M}_{\text {maks }}$ sebesar 31,84844 emu/g, dengan nilai medan koersif $\left(\mathrm{H}_{\mathrm{c})}\right.$ sebesar $0.0123 \mathrm{~T}$.
Dengan menggunakan persamaan 1 dan 2 diperoleh nilai suseptibilitas magnetik $31,88 \times 10^{-6} \mathrm{~m}^{3} / \mathrm{kg}$ dan permeabilitas relatif 1,00003188 .

Nilai suseptibilitas tersebut masuk dalam selang nilai suseptibilitas massa dari mineral ilmenit $\left(\mathrm{FeTiO}_{3}\right)$ yaitu $2,38 \times 10^{-6} \mathrm{~m}^{3} / \mathrm{kg} \mathrm{s} / \mathrm{d} 27,8 \times 10^{-6} \mathrm{~m}^{3} / \mathrm{kg}$ dan magnetit $\left(\mathrm{Fe}_{3} \mathrm{O}_{4}\right)$ yaitu $9.55 \times 10^{-6} \mathrm{~m}^{3} / \mathrm{kg} \mathrm{s} / \mathrm{d} 152,8 \times 10^{-6} \mathrm{~m}^{3} / \mathrm{kg}[5]$ Hal ini mengindikasikan bahwa mineral magnetik pasir besi pantai Ambal kecamatan Mirit kabupaten Kebumen berasal dari berbagai jenis yaitu ilmenit $\left(\mathrm{FeTiO}_{3}\right)$ dan magnetit $\left(\mathrm{Fe}_{3} \mathrm{O}_{4}\right)[6]$.

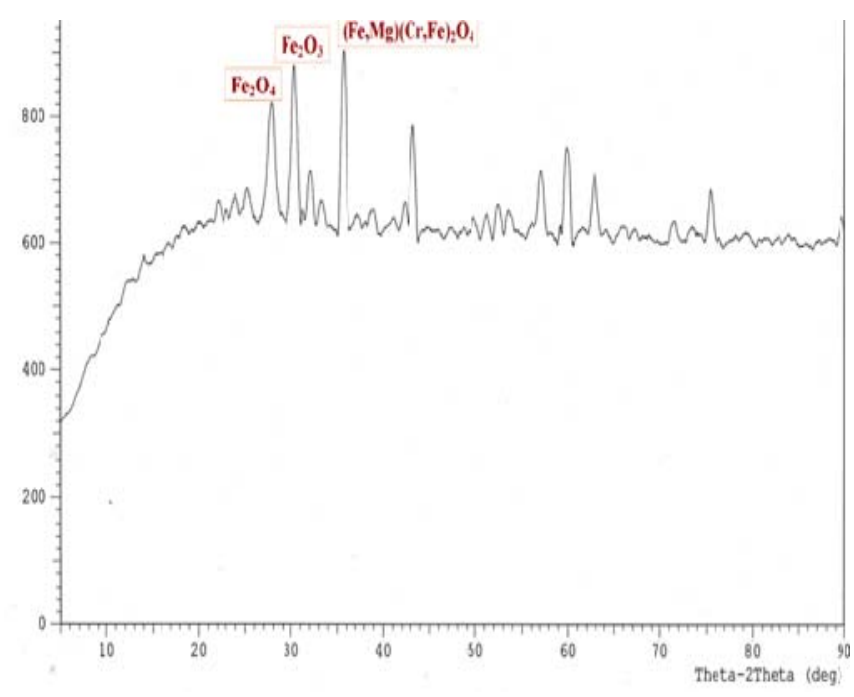

Gambar 1 Hasil XRDi pasir besi dari Pantai Ambal

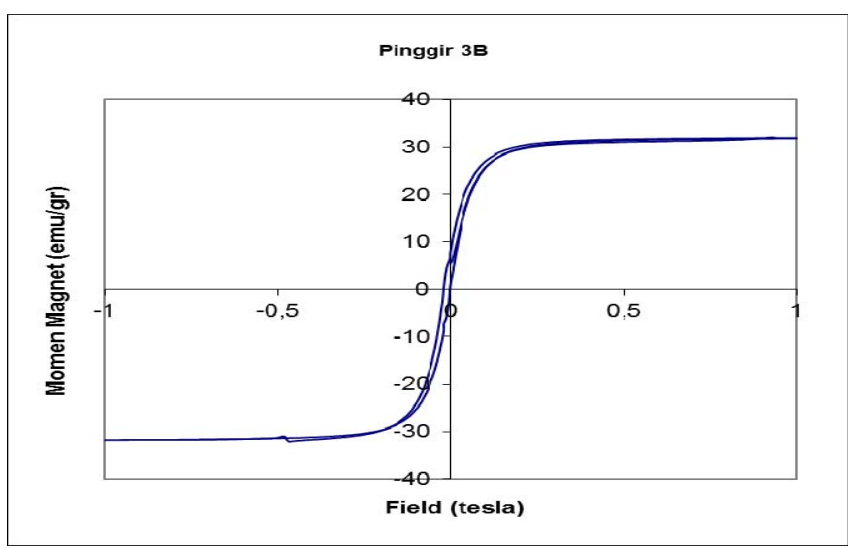

Gambar 2 Karakteristik kurva histerisis sampel pasir besi pantai Ambal

\section{KESIMPULAN}


1. Berdasarkan hasil karakterisasi XRD (X-Ray Diffraction) ditemukan jenis - jenis mineral magnetik yang terkandung pada pasir besi pantai Ambal kabupaten Kebumen adalah Magnetite $\left(\mathrm{Fe}_{3} \mathrm{O}_{4}\right)$, Hematite $\left(\mathrm{Fe}_{2} \mathrm{O}_{3}\right)$, Magnetite Iron Magnesium Chromium Oxide $(\mathrm{Fe}, \mathrm{Mg})(\mathrm{Cr}, \mathrm{Fe})_{2} \mathrm{O}_{4}$.

2. Hasil karakterisasi sifat magnetik menggunakan VSM (Vibrating Sample Magnetometer) menunjukkan bahwa nilai suseptibilitas magnetik pasir besi pantai Ambal kecamatan Mirit kabupaten Kebumen sebesar $31,88 \times 10^{-6} \mathrm{~m}^{3} / \mathrm{kg}$. Berdasarkan nilai permeabilitas yang terhitung maka mineral magnetik pasir pantai Ambal kecamatan Mirit kabupaten Kebumen termasuk dalam kelompok bahan feromagnetik.

\section{UCAPAN TERIMA KASIH}

Penulis mengucapkan terima kasih kepada Saudara Desy Ari Rahmawati atas bantuanya dalam penelitian ini.

\section{PUSTAKA}

[1] Purwanto, Setyo, Membangun Industri Komponen Bahan Magnetik Berbasis Sumber Daya Alam Lokal Melalui Sentuhan Nano Tehknologi. Jurnal Riset Industri, PusatTeknologi Bahan Industri NuklirBATAN : SerpongTangerang Vol 2, 2008.

[2] Bilalodin, Kajian sifat Magnetik dari pasir besi pantai Logending Kabupaten Kebumen, Molekul, vol. 5, no. 2, 2010, pp. 56-108.

[3] Soedojo, P.. Fisika Dasar, Andi , 1994

[4] Yulianto, A., Satria, B., dan Loeksmanto, W., , Karakterisasi Magnetik dari Pasir Besi Cilacap, Jurnal Fisika Himpunan Fisika Indonesia, Vol A5 no 0527 2002.

[5] M Mufit, F, Fadhillah, Amir, H dan Bijaksana, S. Kajian Tantang Sifat Magnetik Pasir Besi Dari Pantai Sunur Pariaman Sumatra Barat. Jurnal Geofisika. Vol 1, 2006. pp 2-5.

[6] Bijaksana, S, , Analisis Mineral Magnetik dalam Masalah Lingkungan, Jurnal Geofisika, Vol.1. 2002, pp 19-27. 